\title{
YIELD AND BIOMETRY OF FERTILIZED SUGAR CANE WITH ORGANOMINERAL FERTILIZER OF SEWAGE SLUDGE AND BIOSTIMULANT
}

\author{
RENDIMENTO E BIOMETRIA DA CANA-DE-AÇÚCAR FERTILIZADA COM \\ FERTILIZANTE ORGANOMINERAL DE LODO DE ESGOTO E BIOESTIMULANTE
}

\author{
Emmerson Rodrigues de MORAES ${ }^{1}$; Reginaldo de CAMARGO²; \\ Regina Maria Q. LANA ${ }^{2}$; Matheus H. MADEIROS ${ }^{2}$; Felipe G. MENEZES ${ }^{2}$; \\ Eduardo P. GIORGENON ${ }^{2}$
}

1. Instituto Federal Goiano, Campus Morrinhos, Morrinhos, GO, Brasil. emmerson.moraes@ifgoiano.edu.br. 2. Universidade Federal de Uberlândia, Campus Glória, Uberlândia, MG, Brasil.

\begin{abstract}
The dependence of mineral fertilizers, increasingly, has brought concern facing the increased demand and because it is a non-renewable mineral resource. The organic fertilization, exclusively, it is impractical in large scale, however, the combination of organic and mineral sources have already proved to be feasible, both from the point of view of nutrition of plants as well as in the aspect of recycling of urban and industrial waste by agriculture. This research had as objective to determine the efficiency of a organomineral fertilizer formulated on the basis of sewage sludge in substitution of mineral fertilizer in the cultivation of sugar cane in environments with different levels of soil fertility. An experiment was conducted in greater soil fertility, in the Institute Federal Goiano- Campus, Morrinhos-GO, Brazil. The other, less soil fertility, was implanted in the ethanol industry Tijuco Valley, located in Rio do Peixe, district of Prata-MG, Brazil. The experimental design was randomized blocks in a factorial $5 \times 2+1$ being five doses, with and without a biostimulant plus an additional with mineral fertilization, in four replications. The doses were in function of fertilization recommendation of planting and coverage for each environment, consisting of: $100 \%$ of the mineral source and percentage $0 ; 60 ; 80 ; 100$ and $120 \%$ of organomineral fertilizer. We evaluated the productivity, tillering, diameter and height of stem in Prata-MG the different percentages of the fertilization of planting favored and increased productivity, height and stem diameter of sugar cane; the use of biostimulants not contributed to increase crop yield. In Morrinhos-GO, the different percentage of planting fertilization did not increase the productivity, tillering, height and diameter of the sugarcane stem; the use of biostimulants increases the productivity yield of sugarcane. Organomineral fertilizer based on biosolids is similar to fertilization with mineral fertilizer in environments.
\end{abstract}

KEYWORDS: Saccharum spp. Fertilizers. Biosolids. Growth. Productivity.

\section{INTRODUCTION}

Brazil is the world's largest producer of sugar cane (Saccharum spp L.), with an expectation around 8.84 million hectares for the 2017/2018 season, with an average yield of $73,728 \mathrm{~kg} \mathrm{ha}^{-1}$, it is expected a production of approximately 646.4 million tonnes (CONAB, 2017). The world sugar production for 2017/18 is estimated at 179.6 million tonnes, having as main producers as in Brazil, India, European Union (sugar beet), Thailand, China and the United States (USDA, 2017).

The cost of fertilizers will be a concern in the future due the grown of demands and by the dependence on non-renewable sources (CÁNOVAS et al., 2018), the dependence on imports of thosenon-renewable sources of nutrients increases the cost of production of sugar cane. The use of biofertilizer has aroused great expectations and concerning about its efficiency, economy, sustainability (RADY, 2012; KULIKOWSKA; GUSIATIN, 2015; LIANG et. al., 2014). Because of the dependence of organic fertilizer source, the biofertilizer opens the possibilities for the recycling of nutrients to the use of sewage sludge (DEEKS et al., 2013). On the cultivation of sugar cane is economically and environmentally important meet the requirement on sustainable actions. Studies of the influence of nitrogen through the use of biofertilizers are being carried out on the culture of sugar cane (DEEKS et al., 2013).

The biofertilizer is gradually being assessed in different cultures and environmental conditions. Recent studies have demonstrated that the culture of sugar cane can respond positively to this type of fertilizer, overcoming the traditional mineral fertilizers (TEIXEIRA; SOUZA; KORNDÖRFER, 2014). Ramos et al. (2017) recommend the 
fertilization with organomineral fertilizer for sugar cane affirming this can replace the mineral fertilizer. There are also reports that the biofertilizer has similar efficiency compared to synthetic fertilizers (SATTOLO et al., 2017). All of this ensures that there is a need for further research. The organomineral fertilizers are an alternative to mineral fertilizers, with the advantage of using environmental liabilities on its composition from productive chains that previously did not have a correct destination as animal manure and trash of agribusiness, as the filter cake.

The processes of sewage treatment aims at separating the solid part of the liquid, so that the treated effluent can return to the receiving bodies without causing damage to the environment (CORRÊA; FONSECA; CORRÊA, 2007). In this process, the sludge becomes rich in organic matter and nutrients, thus being considered as a bioproduct of treatment (BETTIOL et al., 2006). When this residue is treated for later use in agriculture as fertilizer, it is renamed as a biosolid created by the Water Enviromental 10 Federation (WEF), with the main objective of increasing the diffusion of the knowledge of the benefits of this material (PIRES; MATTIAZZO, 2008).

The biosolid is a solid residue resulting of slush from municipal sewage treatments- ETE (YILMAZ; WZOREK; AKÇAY, 2018). The total production of sewage sludge on european the countries in the year 2015 ranged between 1.94 (EUROSTAT, 2017) and 0.94 (DEEKS et al., 2013) billion tons. The biosolids is composed of organic matter, nutrients and some potentially toxic elements (YILMAZ; WZOREK; AKÇAY, 2018). It is important to give a correct destination to the residue, especially from an environmental point of view. Thus, the use of biosolids in agriculture stands out as a viable practice on the environmental point of view, social, economic and agronomic (DEEKS et al., 2013). Resende Júnior et al. (2016) concluded that the organomineral fertilizer, the basis of biosolids, has agronomic benefits that may produce social and environmental gains with less impact on public health.

Some additional technologies have been used in agriculture to increase the quantity and quality of crops. Biostimulants are natural or synthetic substances that can be applied directly to plants to alter their vital and structural processes. Its increase can improve the production and quality of crops of economic interest (SILVA; CATO; COSTA, 2010; FERREIRA; FERREIRA; BOLONHEZI, 2013). The application of biostimulants improves the hormonal balance of the plant, reducing the susceptibility to stresses (SHARMA et al., 2016). These are products that has great potential for use in agriculture. There are many substances that con produce these products, mainly plant hormones such as gibberellins, cytokinins, ethylene and other analogous (SILVA; CATO; COSTA, 2010) in addition to elements such as silicon considered a fertilizer (SAVVAS; NTATSI, 2015).

The efficiency and productivity of sugar cane, as well as other crops, are dependent of sufficient quantity and good balance of nutrients on the soil. Fertilizers which its basis are sewage sludge supplemented with mineral fertilizers are alternatives that ensure that need. Chiba, Mattiazzo and Oliveira (2009) studied the mineral fertilization and fertilization with sewage sludge. They observed the better productivity with mineral fertilizer alone. There is also an increase of productivity using only sewage sludge $\left(8.2 \mathrm{t} \mathrm{ha}^{-1}\right)$ on the furrow at planting compared to absence of fertilizer.

The objective was to evaluate the yield and the biometrics of the sugar cane cultivated with mineral fertilizer and organomineral the basis of biosolids, on the presence and absence of Biostimulant.

\section{MATERIAL AND METHODS}

\section{Experiment in Morrinhos-GO}

The first experiment was carried out at Federal Institute of Education, Science and Technology, Campus Morrinhos Goiás, Brazil, located at coordinates $17^{\circ} 48^{\prime} 33.7^{\prime \prime} \mathrm{S}$ and $49^{\circ} 12^{\prime}$ $19.9^{\prime \prime} \mathrm{W}$, at an altitude of 900 meters. The soil is classified as a dystrophic Red-Yellow Latosol (RYLd) (EMBRAPA, 2013). Meteorological data were collected by the meteorological station of the Campus Morrinhos-GO (Figure 1).

Since fifteen years was cultivated corn and soybeans in alternate years on this area, leaving aside in the remaining months of the year, in all seasons. Samples were taken from soil at depths of 0 to $20 \mathrm{~cm}$ and 20 to $40 \mathrm{~cm}$ (Table 1).

The physical characterization of the soil presented $40.9 \%$ of clay, silt and $21.2 \%$ to $37.9 \%$ of sand. The phosphorus were $800 \mathrm{~kg} \mathrm{ha}^{-1}$ of yorim thermophosphate (16\% P2O5; $18 \% \mathrm{Ca} ; 7 \% \mathrm{Mg}$; $0.10 \% \mathrm{~B} ; 0.05 \% \mathrm{Cu} ; 0.30 \% \mathrm{Mn} ; 10 \%$ itself; $0.55 \%$ $\mathrm{Zn}$ ), followed by harrowing with intermediate roading grid $16 \times 28$ " and leveling of the soil with level grid 36 x $22 "$.

Were sown $30 \mathrm{~kg} \mathrm{ha}^{-1}$ of seeds of Crotalaria juncea, and the intense flowering to 90 days after sowing was performed the cut. After four months of 
preparing the soil became with the desiccation of 3.0 $\mathrm{L} \mathrm{ha}^{-1}$ of glyfhosate and $1.0 \mathrm{~L} \mathrm{ha}^{-1}$ of 2, 4-D. The furrows for planting were opened by a track opener with opening of the rod 52 to $82 \mathrm{~cm}$ and $50 \mathrm{~cm}$ in height. In June 2015 were planted billets from cultivar RB 92579 with 15 to 18 viable buds metro ${ }^{-1}$ at a depth of $30 \mathrm{~cm}$. The planting fertilization was $470 \mathrm{~kg} \mathrm{ha}^{-1}$ formulation 04-21-07 and coverage of $400 \mathrm{~kg} \mathrm{ha}^{-1}$ of $07-00-28+0.7 \%$ of B to 150 days after planting (DAP) (ALVAREZ et al., 1999).

Table 1. Chemical characterization of soils of the experimental areas before the installation of the test.

\begin{tabular}{|c|c|c|c|c|c|c|c|c|c|c|c|}
\hline \multirow{2}{*}{$\begin{array}{l}\text { Depth } \\
\text { (cm) }\end{array}$} & $\begin{array}{c}\mathrm{pH} \\
\left(\mathrm{H}_{2} \mathrm{O}\right)\end{array}$ & $\mathrm{Ca}$ & $\mathrm{Mg}$ & $\mathrm{Al}$ & $\mathrm{P}$ & K & $\mathrm{H}+\mathrm{Al}$ & $\mathrm{T}$ & V & $\mathrm{m}$ & M.O. \\
\hline & $1: 2,5$ & \multicolumn{3}{|c|}{----- $\mathrm{cmol}_{c} \mathrm{dm}^{-3}---$} & \multicolumn{2}{|c|}{$-m g d^{-3}---$} & \multicolumn{2}{|c|}{$-\mathrm{cmol}_{c} \mathrm{dm}^{-3}-$} & \multicolumn{2}{|c|}{----\%---- } & $-\mathrm{g} \mathrm{kg}^{-1}$ \\
\hline \multicolumn{12}{|c|}{ YLd - Prata - MG } \\
\hline $0-20$ & 5,7 & 1,1 & 0,5 & 0,0 & 6,7 & 88 & 1,2 & 3,03 & 60 & 0 & 2,0 \\
\hline $20-40$ & 4,7 & 1,0 & 0,3 & 0,2 & 2,3 & 70 & 1,6 & 3,08 & 48 & 9 & 1,4 \\
\hline \multicolumn{12}{|c|}{ RYLd - Morrinhos - GO } \\
\hline $0-20$ & 6,0 & 2,1 & 0,6 & 0,0 & 11,6 & 136 & 2,5 & 5,55 & 55 & 0 & 2,7 \\
\hline $20-40$ & 5,9 & 1,2 & 0,3 & 0,0 & 3,0 & 55 & 2,5 & 4,14 & 40 & 0 & 1,1 \\
\hline
\end{tabular}

$1 \mathrm{pH}$ in $\mathrm{H} 2 \mathrm{O} ; \mathrm{Ca}, \mathrm{Mg}, \mathrm{Al},\left(\mathrm{KCl} 1 \mathrm{~mol} \mathrm{~L}^{-1}\right) ; \mathrm{P}, \mathrm{K}=\left(\mathrm{Mehlich}^{-1}\right) ; \mathrm{H}+\mathrm{Al}=(\mathrm{SMP}$ to $\mathrm{pH} 7.5) ; \mathrm{CEC}$ at $\mathrm{pH} 7.0 ; \mathrm{V}=$ saturation; $\mathrm{m}=$ aluminum saturation, Methodologies based on Embrapa (2011).

\section{Experiment in Prata-MG}

The experiment was developed in a pasture area with lower soil fertility at Vale do Tijuco Sugar Cane Plant, located in Rio do Peixe, district of Prata, Minas Gerais, Brazil, located at coordinates $19^{\circ} 30^{\prime}$ $01.7^{\prime \prime} \mathrm{S}$ and $48^{\circ} 28^{\prime} 31.8^{\prime \prime} \mathrm{W}$, at an altitude of 780 meters. The soil is classified as a dystrophic Yellow Latosol (YLd) (EMBRAPA, 2013) situated approximately 200 meters upstream of a spring of water. The same remains moist to an average depth of $40 \mathrm{~cm}$ in the most dry season of the year. Meteorological data were collected by an automatic weather station of Instituto Nacional de Meteorologia - INMET - Uberlândia - MG. (Figure $1)$.

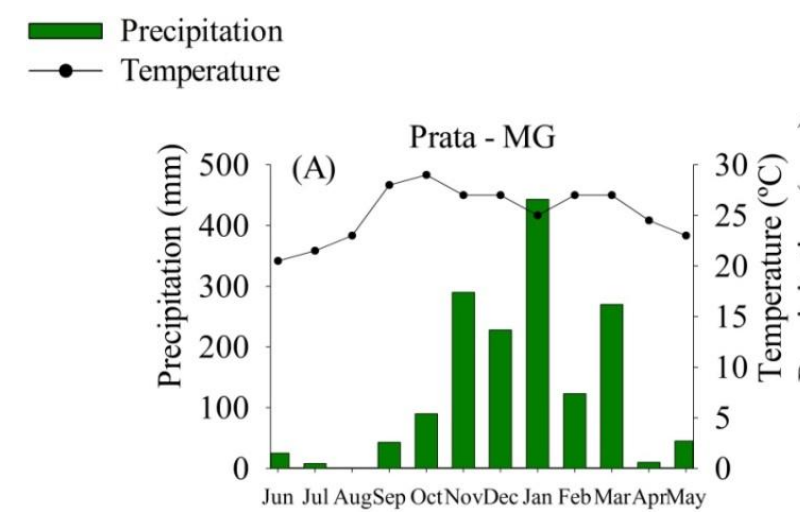

Figure 1. Average precipitation $(\mathrm{mm})$ and temperature $\left({ }^{\circ} \mathrm{C}\right)$ the experimental areas during the crop cycle in season 2015/2016.

The cultivated pasture area presented signs of degradation. The result of sampling and chemical analysis at depths of 0 to $20 \mathrm{~cm}$ and 20 to $40 \mathrm{~cm}$ is represented in Table 1 . The soil is sandy with 18.5 $\%$ of clay, silt $9.5 \%$ and $72.0 \%$ of sand. The liming was performed with $2.4 \mathrm{t} \mathrm{ha}^{-1}$ of dolomitic lime. He became a plowing with moldboard plow with a cutting width of $28.8 \mathrm{~cm}$ spaced $81 \mathrm{~cm}$ and later leveling the soil with harrow disc $36 \times 22 "$. It was planted from 15 to 18 meter viable buds through seedlings at depths of 30 to $40 \mathrm{~cm}$ deep. The experiment was established in May 2015, using the cultivar RB 92 579. The fertilization recommendation of planting was $570 \mathrm{~kg} \mathrm{ha}^{-1}$ formulation 04-21-07 and coverage of $570 \mathrm{~kg} \mathrm{ha}^{-1}$ of $07-00-28+0.7 \%$ of B to 150 DAP (ALVAREZ et al., 1999).

The Organomineral fertilizer was produced from sewage sludge sanitized extracted from sewage treatment station of the Municipal Department of Water and Sewage from the city of Uberlandia-MG. The sewer was centrifuged separating the solids. The sewage sludge contains $70 \%$ moisture and $30 \%$ solids. The sewage sludge, when damp went 
through chemical treatment incorporating whith $30 \%$ of hydrated lime on the solid part exists in the centrifuged. After incorporate it with the use of concrete mixer, the material was packaged in rectangular galvanized zinc containers $(30$ x 30 x $100 \mathrm{~cm}$ ). These were covered by a transparent canvas and exposed to sunlight and ultra violet rays for 15 consecutive days. Subsequently, withdrew the canvas were leaved to dry in the sun until approximately 30 days, stabilizing at $20 \%$ of moisture. The chemical characterization of biosolids was performed according to Embrapa (2011) (Table 2).
Based on the chemical composition of biosolids and the requirement of planting fertilization was mixed forming the formulation 0421-07. Was mixed if $39.3 \%$ of biosolids, $12.2 \%$ of bran potassium chloride $\left(58 \% \mathrm{~K}_{2} \mathrm{O}\right), 47 \%$ of monoamônico phosphate (12\% and $44 \%$ of $\mathrm{P}_{2} \mathrm{O}_{5}$ ) and $1.5 \%$ of water. For the fertilization of coverage (formulation $07-00-28+0.7 \%$ of $\mathrm{B}$ ) was homogenized in $31 \%$ of biosolids, $15 \%$ of urea polymerized ( $45 \%), 48.3 \%$ of potassium chloride, $4.2 \%$ of boric acid and $1.50 \%$ of water.

Table 2. Chemical characterization of biosolids in dry basis at $110^{\circ} \mathrm{C}$.

\begin{tabular}{|c|c|c|c|c|c|c|c|c|c|c|}
\hline $\begin{array}{c}\mathrm{pH} \\
\mathrm{CaCl}_{2}\end{array}$ & UT & NT & MOT & CT & RMT & $\mathrm{C} / \mathrm{N}$ & $\mathrm{P}$ & K & $\mathrm{Ca}$ & $\mathrm{Mg}$ \\
\hline 8,10 & 10,96 & 0,99 & 49,90 & 27,72 & 50,67 & $28 / 1$ & 2,80 & 0,30 & 8,25 & 2,48 \\
\hline $\begin{array}{r}\text { Density } \\
\mathrm{g} \mathrm{cm}^{-3}\end{array}$ & B & $\mathrm{Na}$ & $\mathrm{Mn}$ & $\mathrm{Cu}$ & $\mathrm{Zn}$ & $\begin{array}{r}\mathrm{Fe} \\
\mathrm{g}^{-1}\end{array}$ & $\mathrm{Cd}$ & $\mathrm{Hg}$ & $\mathrm{Cr}$ & $\mathrm{Ni}$ \\
\hline 0,66 & 10 & 201 & 209 & 135 & 1042 & 27236 & 1,4 & 0,7 & 931 & 250 \\
\hline
\end{tabular}

UT = Total Moisture; NT $=$ Total nitrogen; MOT $=$ Organic matter; $\mathrm{CT}=$ Total Carbon; RMT $=$ Total Mineral residue. $\mathrm{N}-[\mathrm{N}]=$ sulfuric acid digestion. $\mathrm{P}, \mathrm{K}, \mathrm{Ca}, \mathrm{Mg}, \mathrm{S}, \mathrm{Cu}, \mathrm{Fe}, \mathrm{Mn}, \mathrm{Zn}=$ perchloric digestion Nitro. $\mathrm{B}=$ Colormetric azomethine-H). Methodologies based on Embrapa (2011).

The experimental design was in randomized blocks factorial $5 \times 2+1$ being five doses, with and without a biostimulant plus an additional (mineral fertilization) in four replications. The experimental units corresponded to $9.0 \mathrm{~m}$ wide x $10.0 \mathrm{~m}$ long, composed by six rows of sugar cane in the spacing of $1.5 \mathrm{~m}$. The area was composed by four central rows of each plot disregarding $1.0 \mathrm{~m}$ in each end totaling $48 \mathrm{~m}^{2}$. The total area of each plot was $90 \mathrm{~m}^{2}$ and the carriers were spaced $3.0 \mathrm{~m}$ between plots and blocks. It was used biostimulant to the roots containing $0.09 \mathrm{~g} \mathrm{dm}^{-3}$ kinetin, $0.05 \mathrm{~g} \mathrm{dm}^{-3}$ of acid 4-indole-3-ilbutírico and $0.05 \mathrm{~g} \mathrm{dm}^{-3}$ of gibberellic acid) via inoculation $\left(0.75 \mathrm{~L} \mathrm{ha}^{-1}\right)$ and spray volume of $100 \mathrm{~L} \mathrm{ha}^{-1}$ on the sugar canestick in the furrow at planting.

The combinations of doses on treatments were in function of fertilization recommendation planting and coverage for each environment, consisting of: $100 \%$ of the mineral source; and percentage $0 ; 60 ; 80 ; 100$ and $120 \%$ of organomineral fertilizer (with and without a biostimulant).To control weeds were used herbicides diuron, hexazinone and MSMA in doses of 3.2; 5.0 and $3.0 \mathrm{~L} \mathrm{ha}^{-1}$, respectively. The control of ants and termites was carried out with the active principle fipronil applied in the planting furrow at a dosage of $2.5 \mathrm{~g} \mathrm{ha}^{-1}$.
It was evaluated yield $\left(\mathrm{t} \mathrm{ha}^{-1}\right)$ at the time of harvest to 370 DAP. The harvest was performed manually by cutting $8.0 \mathrm{~m}$ of plot being $2.0 \mathrm{~m}$ in each line. The beam of sugarcane was weighed with weighing dynamometer Technical mark mod. D5000 and weighing capacity $2000 \mathrm{~kg} \mathrm{x} 200 \mathrm{~g}$.

It was performed like this in order to count the number of tillers in eight central meters of four lines were useful. The diameter was determined with a digital caliper at the time of the third ascending stem. For the height using a measuring tape from the cut at the base of the stem to the opposite end of the cut.

\section{Statistical analysis}

The results were submitted to analysis of variance (ANOVA), carried out by the F test at 5\% probability, and the averages were compared by the Tukey test and Dunnet's test at 0.05 significance level through software Assistat 7.7 Beta (SILVA; AZEVEDO, 2009). The adjustment of the regression equations were chosen based on the significance of the regression coefficients at 5\% probability by the $\mathrm{F}$ test and the largest determination coefficient $\left(\mathrm{R}^{2}\right)$ Sigma Plot for Windows (Systat Inc., Chicago, IL, USA) version 12.0. Comparison was performed between two environments using the 5.1 software Genes (CRUZ, 2013). 


\section{RESULTS AND DISCUSSION}

In the trial installed on the locality of PrataMG, whose level of fertility of the soil presents chemical characteristics more restrictives for the cultivation of sugar cane in relation to the locality of Morrinhos-GO, the absence of fertilization promoted significant reductions on productivity, height, stem diameter and tillering in relation to nitrogen standard, corresponding to mineral fertilization (Table 3). Thus, while the mineral fertilization with $100 \%$ of the recommendation promoted a yield of $113.1 \mathrm{t} \mathrm{ha}^{-1}$, in the absence of fertilization, the productivity was 53.9 and $62.2 \mathrm{t} \mathrm{ha}^{-}$ ${ }^{1}$ without and with biostimulant, respectively. There were no differences for the remaining percentage of fertilization. The imbalance and nutritional deficiency to the agricultural crops is a determinant factor for the occurrence of low yields (DOAN et al., 2015).

Table 3. Productivity, height and stem diameter and tillering function of the percentage of the dose recommendation for mineral fertilization and organomineral with and without biostimulant in Prata MG.

\begin{tabular}{|c|c|c|c|c|c|c|}
\hline \multirow{2}{*}{ Biostimulant } & \multirow[b]{2}{*}{0} & \multicolumn{5}{|c|}{ - } \\
\hline & & 60 & 80 & 100 & 120 & Media \\
\hline \multicolumn{7}{|c|}{ - Productivity $\left(\mathrm{t} \mathrm{ha}^{-1}\right)$ - } \\
\hline Whithout & $53,9 *$ & 95,5 & 115,0 & 109,6 & 124,8 & $99,8 \mathrm{~A}$ \\
\hline With & $62,3 *$ & 98,9 & 100,4 & 110,0 & 121,4 & $98,6 \mathrm{~A}$ \\
\hline \multirow{2}{*}{\multicolumn{7}{|c|}{$\begin{array}{c}\text { Mineral } 100 \%=113,1 \\
\mathrm{CV}(\%)=14,92 ; \mathrm{DMS}_{\text {Biostimulant }}=9,69 ; \mathrm{DMS}_{\text {Mineral }}=30,64\end{array}$}} \\
\hline & & & & & & \\
\hline \multicolumn{7}{|c|}{$\mathrm{C} V(\%)=14,92 ; \mathrm{DMS}_{\text {Biostimulant }}=9,69 ; \mathrm{DMI}_{\text {Mineral }}=30,64$} \\
\hline Whithout & $1,70^{*}$ & 2,30 & 2,47 & 2,44 & 2,41 & $2,26 \mathrm{~A}$ \\
\hline With & $1,79 *$ & 2,36 & 2,49 & 2,33 & 2,44 & $2,28 \mathrm{~A}$ \\
\hline \multirow{2}{*}{\multicolumn{7}{|c|}{$\begin{aligned} \text { Mineral } 100 \% & =2,26 \\
\mathrm{CV}(\%)=6,48 ; \mathrm{DMS}_{\text {Biostimulant }} & =; \mathrm{DMS}_{\text {Mineral }}=0,30\end{aligned}$}} \\
\hline & & & & & & \\
\hline \multirow{5}{*}{\multicolumn{7}{|c|}{$\begin{array}{rrrrr}-27,73 & 28,04 & 28,61 & 29,43 & 27,26 \mathrm{~A} \\
27,34 & 28,49 & 29,78 & 31,10 & 27,94 \mathrm{~A} \\
\mathrm{CV}(\%)=4,50 ; \mathrm{DMS}_{\text {Bioetimulant }}=0,80 ; \mathrm{DMS}_{\text {Mineral }}=2,55 & \\
\end{array}$}} \\
\hline & & & & & & \\
\hline & & & & & & \\
\hline & & & & & & \\
\hline & & & & & & \\
\hline \multicolumn{7}{|c|}{ 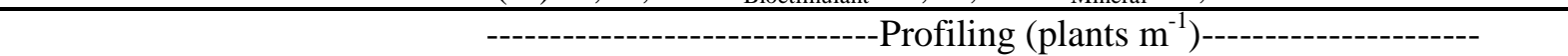 } \\
\hline Whithout & 10,0 & 10,5 & 11,6 & 11,5 & 11,1 & $10,9 \mathrm{~A}$ \\
\hline With & $9,5^{*}$ & 11,3 & 11,8 & 10,8 & 11,6 & $11,0 \mathrm{~A}$ \\
\hline \multicolumn{7}{|c|}{ Mineral $100 \%=11,5$} \\
\hline
\end{tabular}

Medias followed by different letters, in the column for each variable, differ among themselves by the test of Tukey at 0.05 significance level; *different averages of the mineral by Dunnet's test $(\mathrm{p}<0.05)$.

Even if we have observed rainfall rates higher than those of Morrinhos-GO (Figure 1), a condition that favors the greater efficiency of nitrogen, were not observed in the experiment of Prata-MG significant differences on the parameters evaluated between the mineral fertilizer and organomineral at its different levels. The lower buffer capacity of the soil has to be limiting in the absence of fertilizer (JIANG et al. 2016). However, it is important to highlight that even using the Organomineral fertilizer at a dosage of $60 \%$ of the recommendation, there was a reduction only in average diameter of stem, when compared to mineral fertilization, keeping unchanged the other factors of production (Table 3 ). In contrast, even at a dose of $120 \%$ the fertilizer organomineral did not result in significant gains in relation to mineral fertilization. From the rate of $60 \%$ was sufficient to ensure the proper development of the plants producing similar to rate of $120 \%$. Soils of high fertility can ensure good or better productivity of sugar cane (GOLDEMBERG; COELHO; GUARDABASSI, 2008). Kirkels, Cammeraat and Kuhn (2014) emphasizes the need to be replenishing nutrients in function of extraction by crops and thus remain close to the ideal for cultivation.

Under climate conditions and soil from the municipality of Prata-MG was not observed significant effect arising from the application of the biostimulant in the evaluation performed at 370 DAP on the parameters evaluated. The hormonal compound (kinetin acid, 4-indole-3-ilbutírico and 
gibberellic acid) not contributed to increase the efficiency of absorption of nutrients from the soil solution. On the other hand, Ferreira, Ferreira and Bolonhezi (2013) affirm that the hormonal compound improves nutrient absorption and helps to support the strict conditions of soil fertility.

In an experiment installed in Morrinhos-GO

(Table 4), the higher fertility of the soil promoted quite different results in relation to the observed in the municipality of Prata-MG. Should also be considered that previously to the test, the area was cultivated for over a decade with corn and soybean in succession, having received phosphorus and the management of scouring, desiccation and incorporation of Crotalaria juncea, before planting of sugar cane. Thus, even in the absence of fertilization, were obtained the same productivity, height and stem diameter and number of tillers observed in the treatment with mineral fertilizer. Best fertility soils have greater resistance to change or depletion of nutrients in the soil (DOAN et al., 2015). Thus, the supply of nutrients to the plants are larger and promote the best development of the plants (YAN et al., 2016). Attention to the good performance of plots that received organomineral fertilizer with dosage of $60 \%$ of the recommendation, not differing mineral fertilization supplied at a dose of $100 \%$. Characteristics inherent to the production technology gives the fertilizer organomineral ownership of controlled release, with the possible reduction of leaching, remaining at the disposal of the root system for a longer period of time (KOMINKO; GORAZDA; WZOREK, 2017). In theory, this could contribute to explain the greater efficiency of biofertilizer in fertilizer trials with different cultures.

In Morrinhos-GO conditions it was evidenced significant effect of biostimulant Evidenced significant effect of biostimulant in the average increase in yield in crop productivity in $13.4 \mathrm{t} \mathrm{ha}^{-1}$ comparing with the absence, while for the other parameters there were no significant gains. The development of the root system and aerial part is favored by the increase of cellular division and organogenesis of tissues. Thus, there is a greater production of photoassimilates and consequently productivity. The stimulator assists responses to adaptations of plants to extrinsic factors, mediating the reception of light in the aerial part, improving the absorption of water and nutrients to the roots (KOPRNA et al., 2016). Silva, Cato and Costa (2010) and Ferreira, Ferreira and Bolonhezi (2013) reported increases in productivity of ton of stalks per hectare and sugar in sugarcane ratoon regardless of genotype, with the use of biorreguladores vegetables. The biostimulanthelp to maintain the hormonal balance of the plant, making them less susceptible to biotic and abiotic stresses (SHARMA et al., 2016).

On the area of lower fertility in Prata-MG, it was observed that average productivity (Figure 2B) and stem diameter (Figure 2F) with the use of a biostimulant adjusted the ascending linear regressions.

The maximum productivity and increased stem diameter recorded at a dose of $120 \%$ were respectively $47 \mathrm{t} \mathrm{ha}^{-1}$ and $31.51 \mathrm{~mm}$ with the use of a stimulator. In soils with low nutrient supply occurs massive responses to nitrogen supplied. This was evident by the agronomic performance of green cane fertilized with ammonium sulphate in a soil of the coastal plain found by (OLIVEIRA et al., 2017). Replacement of nutrients is emphasized by (KIRKELS; CAMMERAAT; KUHN, 2014) in function of extraction by crops and thus remain close to the ideal for cultivation.

Table 4. Productivity, height and stem diameter and tillering function of the percentage of the dose recommendation for mineral fertilization and organomineral with and without biostimulant in Morrinhos - GO.

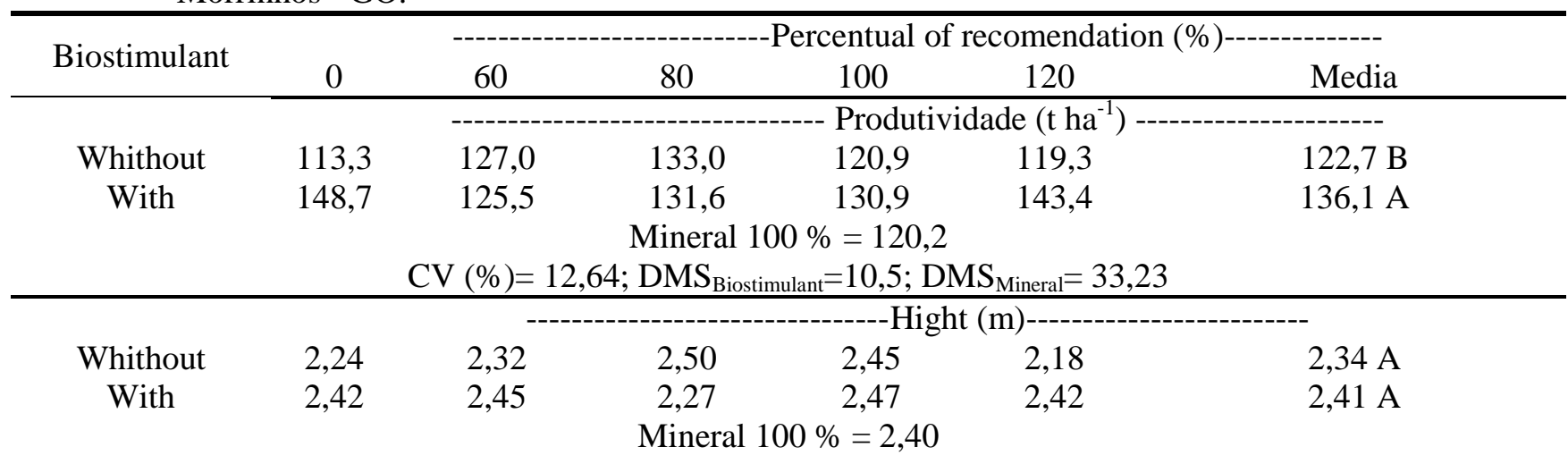


$\mathrm{CV}(\%)=7,50 ; \mathrm{DMS}_{\text {Biostimulant }}=0,11 ; \mathrm{DMS}_{\text {Mineral }}=0,36$

\begin{tabular}{|c|c|c|c|c|c|c|}
\hline \multirow{3}{*}{$\begin{array}{l}\text { Whithout } \\
\text { With }\end{array}$} & \multirow{3}{*}{$\begin{array}{l}27,77 \\
28,37\end{array}$} & \multicolumn{5}{|c|}{ 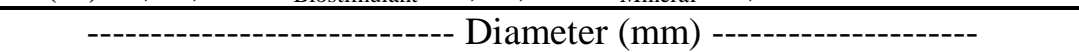 } \\
\hline & & 29,19 & 28,91 & 28,64 & 29,0 & $28,70 \mathrm{~A}$ \\
\hline & & 28,78 & 29,37 & 29,78 & 30,64 & $29,39 \mathrm{~A}$ \\
\hline \multicolumn{7}{|c|}{$\begin{array}{c}\text { Mineral } 100 \%=29,82 \\
\mathrm{CV}(\%)=4,47 ; \mathrm{DMS}_{\text {Biostimulant }}=0,84 ; \mathrm{DMS}_{\text {Mineral }}=2,66\end{array}$} \\
\hline \multicolumn{7}{|c|}{ 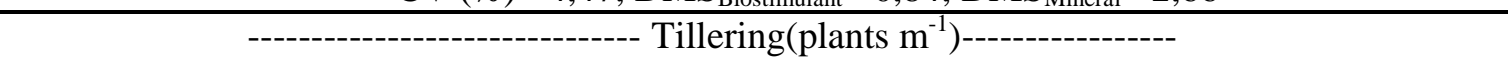 } \\
\hline Whithout & 91,50 & 96,72 & 95,26 & 86,87 & 92,0 & $92,47 \mathrm{~A}$ \\
\hline With & 94,76 & 94,25 & 96,31 & 91,18 & 96,76 & $94,65 \mathrm{~A}$ \\
\hline \multicolumn{7}{|c|}{$\begin{array}{c}\text { Mineral } 100 \%=94,76 \\
\mathrm{CV}(\%)=8,61 ; \mathrm{DMS}_{\text {Biostimulant }}=5,21 ; \mathrm{DMS}_{\text {Mineral }}=16,48\end{array}$} \\
\hline
\end{tabular}

Medias followed by different letters, in the column for each variable, differ among themselves by the test of Tukey at 0.05 significance level; *different averages of the mineral by Dunnet's test $(\mathrm{p}<0.05)$.

The productivity averages (Figure $2 \mathrm{~A}$ ) and stem diameter (Figure 2E) without use of biostimulants were adjusted to quadratic regressions. While in the absence of biostimulant the maximum productivity of $122.4 \mathrm{t} \mathrm{ha}^{-1}$ was obtained in the dosage of $120 \%$, the maximum diameter of $29.2 \mathrm{~mm}$ also in the dosage of $120 \%$.

The average plant height adjusted to quadratic regressions without (Figure 2C) and (Figure 2D) biostimulant. However, while in the absence of the biostimulant maximum height of 2.45 $\mathrm{m}$ was obtained at a dosage of $100 \%$, when the use of the stimulator the maximum height was $2.44 \mathrm{~m}$ at a dosage of $94.6 \%$. Justified by the inverse of the happened in the area in Morrinhos-GO. In this way, the responses of the crop with the application of the biostimulant is dependent on the provision of nutrients in the soil solution. Thus, the increasing production of photoassimilates and consequently productivity of sugar cane is dependent on a better nutrition and absorption capacity. From then on, the biostimulant assists the plants to support diversity of different factors (KOPRNA et al., 2016; SHARMA et al., 2016).

On the other hand, no differences were found on nitrogen percentage in the area of greater soil fertility in Morrinhos-GO. As already mentioned, the textural characteristics, history of cultivation, phosphorus, cultivation of Crotalaria juncea has improved and increased the buffer capacity of the soil giving greater resistance to change variations in nutrient levels available in the soil solution (DOAN et al., 2015). 

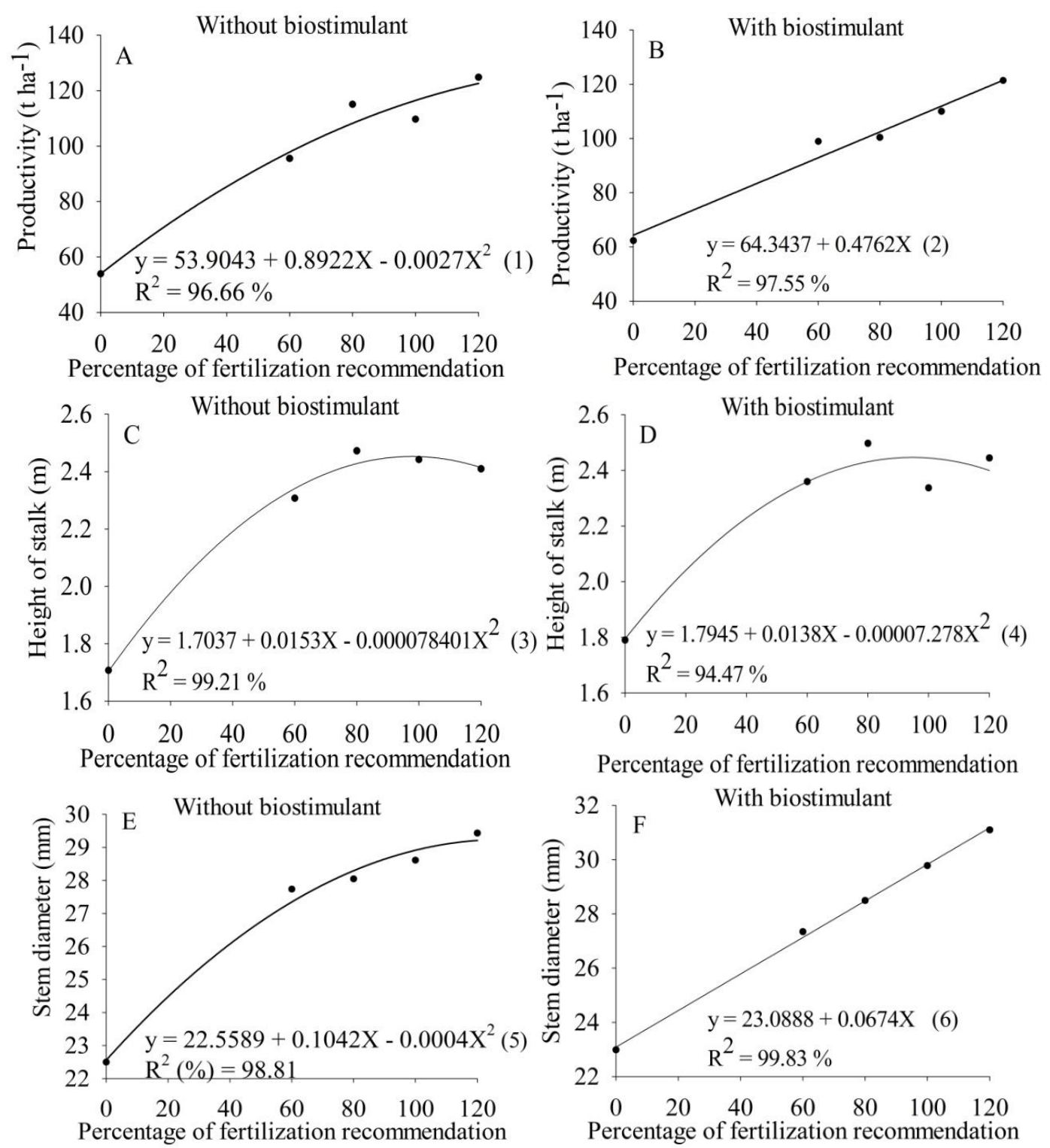

Figure 2. Regression models were significant at 0.05 , for productivity, height and stem diameter and tillering in function of doses of Organomineral the basis of biosolids with and without biostimulant in area of lower soil fertility in Prata - MG.

In Table 5are presented comparisons by Tukey test between the averages of productivity and growth parameters of plants in the localities of Prata-MG and Morrinhos-GO. In the last locality, the best agronomic characteristics of the soil resulted in significant differences $(\mathrm{P} \geq 0.05)$ between the environments for all parameters evaluated when in the absence of fertilization, particularly with regard to the productivity that was $54.76 \%$ higher in the test installed in the Goiás state without the application of the biostimulant and $46.60 \%$ in the presence of the stimulator. There is, however, that the mineral fertilization promoted equivalence of productivity, height and stem diameter and tillering between both locations. Possibly the greatest speed of dissolution of mineral fertilizer, elevation in the levels of elements provided the soil solution and consequent availability for the plant may have favored the similarity between the averages in both locations. The supply of nutrients are larger and contained in soils of higher level of fertility by promoting the best development of the plants (YAN et al., 2016). Tomei (2015) cites the competition for land in fertile volcanic soils of the pacific coast in the region of Guatemala for the cultivation of sugar cane. 
Table5. Productivity, stem height, stem diameter and tillering of plants of sugar cane cultivated in two environments (Prata-MG and Morrinhos-GO) depending on the percentage of fertilization with and without biostimulant.

\begin{tabular}{|c|c|c|c|c|c|c|c|c|c|c|c|}
\hline \multirow{3}{*}{ Locations } & \multicolumn{11}{|c|}{ Percentual of recomendation $(\%)$} \\
\hline & \multicolumn{2}{|c|}{-------- 0 ------- } & \multirow{2}{*}{$\begin{array}{l}\text { Whithout } \\
\text {-----60---- }\end{array}$} & \multirow[b]{2}{*}{ With } & \multirow{2}{*}{$\begin{array}{l}\text { Whithout } \\
\text {-----80--- }\end{array}$} & \multirow{2}{*}{ With } & \multirow{2}{*}{$\begin{array}{l}\text { Whithout } \\
\text {----100--- }\end{array}$} & \multirow[b]{2}{*}{ With } & \multicolumn{2}{|c|}{------120------ } & \multirow{2}{*}{$\begin{array}{c}\text { Mineral } \\
100 \%\end{array}$} \\
\hline & Whithout & With & & & & & & & Whithout & With & \\
\hline & \multicolumn{11}{|c|}{ Productivity $\left(\mathrm{t} \mathrm{ha}^{-1}\right)$} \\
\hline \multirow{4}{*}{$\begin{array}{c}\text { Prata } \\
\text { Morrinhos }\end{array}$} & $53,9 \mathrm{~b}$ & $62,3 \mathrm{~b}$ & $95,5 \mathrm{~b}$ & $98,9 \mathrm{~b}$ & $115,0 \mathrm{a}$ & $100,4 \mathrm{~b}$ & $109,7 \mathrm{a}$ & $110,0 \mathrm{~b}$ & $124,8 \mathrm{a}$ & $121,4 \mathrm{~b}$ & $113,2 \mathrm{a}$ \\
\hline & $108,3 \mathrm{a}$ & $133,7 \mathrm{a}$ & 119,6 a & $128,1 \mathrm{a}$ & $123,1 \mathrm{a}$ & $136,6 \mathrm{a}$ & $123,5 \mathrm{a}$ & $138,5 \mathrm{a}$ & $126,8 \mathrm{a}$ & $143,5 \mathrm{a}$ & $127,7 \mathrm{a}$ \\
\hline & \multicolumn{11}{|c|}{$\mathrm{CV}(\%)=11,2 ; \mathrm{DMS}_{\text {Locations }}=18,2$} \\
\hline & & & & & Heig & hof stalk & (m) & & & & \\
\hline \multirow{3}{*}{$\begin{array}{c}\text { Prata } \\
\text { Morrinhos }\end{array}$} & $1,70 \mathrm{~b}$ & $1,87 \mathrm{~b}$ & $2,32 \mathrm{a}$ & $2,37 \mathrm{a}$ & $2,45 \mathrm{a}$ & $2,50 \mathrm{a}$ & $2,42 \mathrm{a}$ & $2,37 \mathrm{a}$ & $2,42 \mathrm{a}$ & $2,45 \mathrm{a}$ & $2,27 \mathrm{a}$ \\
\hline & $2,25 \mathrm{a}$ & $2,42 \mathrm{a}$ & $2,32 \mathrm{a}$ & $2,45 \mathrm{a}$ & $2,50 \mathrm{a}$ & $2,27 \mathrm{a}$ & $2,45 \mathrm{a}$ & $2,47 \mathrm{a}$ & $2,20 \mathrm{a}$ & $2,42 \mathrm{a}$ & $2,45 \mathrm{a}$ \\
\hline & \multicolumn{11}{|c|}{$\mathrm{CV}(\%)=7,44 ; \mathrm{DMS}_{\text {Locations }}=0,24$} \\
\hline \multirow{4}{*}{$\begin{array}{c}\text { Prata } \\
\text { Morrinhos }\end{array}$} & \multicolumn{11}{|c|}{$\begin{array}{l}\text { Stalk diameter }(\mathrm{mm}) \\
\end{array}$} \\
\hline & $22,4 \mathrm{~b}$ & $22,9 \mathrm{~b}$ & $27,7 \mathrm{a}$ & $27,3 \mathrm{a}$ & $28,0 \mathrm{a}$ & $28,5 \mathrm{a}$ & 28,6 a & $29,7 \mathrm{a}$ & 29,4 a & $31,1 \mathrm{a}$ & $29,8 \mathrm{a}$ \\
\hline & $27,7 \mathrm{a}$ & $28,3 \mathrm{a}$ & $29,2 \mathrm{a}$ & $28,7 \mathrm{a}$ & 28,9 a & 29,4 a & $28,6 \mathrm{a}$ & $29,7 \mathrm{a}$ & $29,0 \mathrm{a}$ & 30,6 a & $29,8 \mathrm{a}$ \\
\hline & \multicolumn{11}{|c|}{$\mathrm{CV}(\%)=4,49 ; \mathrm{DMS}_{\text {Locations }}=1,81$} \\
\hline \multirow{4}{*}{$\begin{array}{c}\text { Prata } \\
\text { Morrinhos }\end{array}$} & \multicolumn{11}{|c|}{ number of tiller (plants $\mathrm{m}^{-1}$ ) } \\
\hline & $10,0 \mathrm{~b}$ & $9,8 \mathrm{~b}$ & $10,4 \mathrm{~b}$ & $11,3 \mathrm{a}$ & $11,6 \mathrm{a}$ & $11,8 \mathrm{a}$ & $11,6 \mathrm{a}$ & $11,8 \mathrm{a}$ & $11,1 \mathrm{a}$ & $11,7 \mathrm{a}$ & $11,5 \mathrm{a}$ \\
\hline & $11,4 \mathrm{a}$ & $11,8 \mathrm{a}$ & $12,1 \mathrm{a}$ & $11,7 \mathrm{a}$ & $11,9 \mathrm{a}$ & $12,0 \mathrm{a}$ & $10,8 \mathrm{a}$ & $11,4 \mathrm{a}$ & $11,5 \mathrm{a}$ & 12,1 & $11,8 \mathrm{a}$ \\
\hline & \multicolumn{11}{|c|}{$\mathrm{CV}(\%)=8,13 ; \mathrm{DMS}_{\text {Locations }}=1,31$} \\
\hline
\end{tabular}

Averages followed by different letters, in column, differ among them selves by the test of Tukey at 0.05 significance level. 
When is used organomineral fertilizer, the extent that was used fertilization levels between 80 and $120 \%$ of the recommended dose, the differences between the two environments for the averages observed in the parameters evaluated are not detectable. It seems that, regardless of the type of fertilizer, the correction of levels of essential elements to plants occurred on a satisfactory way

In environment of lower soil fertility (PrataMG) the different percentages of the fertilization of planting increase the productivity, height and diameter of the cane of the sugar cane; the use of biostimulants does not contribute to the yield of this crop.

In environment of greater soil fertility (Morrinhos-GO) the different percentages of the fertilization of planting do not improve productivity, tillering, height and diameter of the cane of sugarcane; the use of biostimulants increases yield of sugarcane.
Organomineral fertilizer based on biosolids can replace fertilizing with mineral fertilizer environments of low and high fertility.

The use oforganomineral fertilizer and biostimulant are viable alternatives for sustainable fertilization of the soil and the cycling of nutrients on the culture of sugar cane.

\section{ACKNOWLEDMENS}

To the Conselho Nacional de Desenvolvimento Científico e Tecnológico - CNPq; the Fundação de Amparo à Pesquisa do Estado de Minas Gerais - FAPEMIG; Mining Company of Sugar and Alcohol - Cmaa - Valley of the Tijuco; Araporã Bioenergy; Stoller of Brazil; Instituto Federal Goiano - Campus Morrinhos and Instituto de Ciências Agrárias - Federal University of Uberlândia.

RESUMO:A dependência de fertilizantes minerais, cada vez mais, trouxe preocupação frente ao aumento da demanda e por ser um recurso mineral não renovável. A adubação orgânica, em exclusivo, é impraticável em larga escala, no entanto, a combinação de fontes orgânicas e minerais já se mostrou viável, tanto do ponto de vista nutricional das plantas como no aspecto de reciclagem de áreas urbanas e urbanas como de resíduos industriais pela agricultura. Esta pesquisa teve como objetivo determinar a eficiência de um fertilizante organomineral formulado à base de lodo de esgoto em substituição ao adubo mineral no cultivo de cana-de-açúcar em ambientes com diferentes níveis de fertilidade do solo. Um experimento foi conduzido em ambiente de maior fertilidade do solo, no Instituto Federal Goiano - Campus, Morrinhos-GO, Brasil. O outro, em local com menor fertilidade do solo, na indústria de etanol no Vale do Tijuco, localizado no município de Rio do Peixe, no município de Prata-MG, Brasil. Utilizou-se o delineamento experimental de blocos ao acaso, em esquema fatorial $5 \times 2+1$, correspondente a cinco níveis de adubação, com e sem bioestimulante mais um tratamento adicional com adubação mineral, em quatro repetições. As doses foram em função da recomendação de adubação de plantio e cobertura para cada ambiente, sendo composta por: $100 \%$ da fonte mineral e porcentagens de 0;60;80;100 e 120\% de fertilizante organomineral. Avaliou-se a produtividade, perfilhamento, diâmetro e altura de colmos.Em Prata - MG os diferentes percentuais da adubação de plantio favorece e incrementa produtividade, altura e diâmetro do colmo da cana-de-açúcar; o uso de bioestimulantes não contribui para o rendimento desta cultura. Em Morrinhos - GO os diferentes percentuais da adubação de plantio não melhora produtividade, perfilhamento, altura e diâmetro do colmo da cana-de-açúcar; o uso de bioestimulantes incrementa rendimento de produtividade da cana-de-açúcar. A adubação com fertilizante organomineral a base de biossólido é semelhante a adubação com fertilizante mineral nos ambientes.

PALAVRAS-CHAVE: Saccharum spp. Fertilizantes. Biossólidos. Crescimento. Produtividade.

\section{REFERENCES}

ALVAREZ, V. V. H.; NOVAIS, R. F, de.; BARROS, N. F, de.; CANTARUTTI, R. B.; LOPES, A. S. Interpretação dos resultados das análises de solos. In: RIBEIRO, A. C., GUIMARÃES, PTG, ALVAREZ V., VH, (1999). Recomendações para o uso de corretivos e fertilizantes em Minas Gerais- $5^{\circ}$ Aproximação. Viçosa: Comissão de Fertilidade do solo do Estado de Minas Gerais, 199p. 25-32. 
BETTIOL, W.; CAMARGO, A. O, de.; GALVÃO, J. A. H.; GHINI, R. Impacto ambiental do uso agrícola do lodo de esgoto: Descrição do Estudo. In: Lodo de Esgoto: impactos ambientais na agricultura. Embrapa Meio Ambiente. 17-23, 2006.Disponível em: http://www.cnpma.embrapa.br/download/LivroLodoEsgoto.pdf. Acesso em: 12 ago 2017.

CHIBA, M. K.; MATTIAZZO, M. E.; OLIVEIRA, F. C. Rendimento de cana-de-açúcar cultivada em argisolo, utilizando lodo de esgoto como fonte de fósforo. ActaScientiarum. Agronomy, v. 31, n.3, 495-501, 2009. http://dx.doi.org/10.4025/actasciagron.v31i3.692.

CONAB - Companhia Nacional de Abastecimento. Acompanhamento da safra brasileira: cana-de-açúcar. V. 4 - SAFRA 2017/18 N. 1 - Primeiro levantamento. Brasília. Disponível em: http://www.conab.gov.br/OlalaCMS/uploads/arquivos/17_04_20_14_04_31_boletim_cana_portugues__1o_lev_-_17-18.pdf. Acesso em: 18 set 2017.

CORRÊA, R. S.; FONSECA, Y. M. F.; CORRÊA, A. S. Produção de biossólido agrícola por meio da compostagem e vermicompostagem de lodo de esgoto.Revista Brasileira de Engenharia Agrícola e Ambiental, v.11, p.420-426, 2007. http://dx.doi.org/10.1590/S1415-43662007000400012

CRUZ, C. D. (2013) GENES - a software package for analysis in experimental statistics and quantitative genetics. Acta Scientiarum, v.35, n.3, p.271-276, 2013.http://dx.doi.org/10.4025/actasciagron.v35i3.21251

DEEKS, L. K.; CHANEY, K.; MURRAY, C.; SAKRABANI, R.; GEDARA, S.; LE, S. M.; TYRREL, S.; PAWLETT, M.; READ, R.; SMITH, G. H. A new sludge-derived organo-mineral fertilizer gives similar crop yields as conventional fertilizers. Agronomy for Sustainable Development, v. 33, n.3, p. 539-549, 2013. https://doi.org/10.1007/s13593-013-0135-z

DOAN, T. T.; HENRY-DES-TUREAUX, T.; RUMPEL, C.; JANEAU, J.; JOUQUET, P. Impact of compost, vermicompost and biochar on soil fertility, maize yield and soil erosion in Northern Vietnam: A three year mesocosm experiment. Science of The Total Environment, v.514, p.147-154, 2015.

https://doi.org/10.1016/j.scitotenv.2015.02.005.

EMBRAPA. EMPRESA BRASILEIRA DE PESQUISA AGROPECUÁRIA. Manual de métodos de análises de solo. 2 ed. Rio de Janeiro: RJ. Embrapa Solos, 2011, 230p.

\section{EMBRAPA. EMPRESA BRASILEIRA DE PESQUISA AGROPECUÁRIA.Sistema Brasileiro de}

Classificação de Solos. $3^{\text {a }}$. ed. Rio de Janeiro: RJ. Embrapa Solos, 2013 350p.

EUROSTAT. Sewage Sludge production and disposal. Disponível

em:http://ec.europa.eu/eurostat/web/products-datasets/-/env_ww_spd.Acesso em $11 \mathrm{dec} .2017$.

FERREIRA, M. M. R.; FERREIRA, L. H. Z.; BOLONHEZI, A. C. Plant regulators applied in the planting furrow in some sugarcane cultivars. Scientia Agraria, v.14, n.2, p.59-64, 2013.

https://www.cabdirect.org/cabdirect/FullTextPDF/2015/20153189440.pdf.

https://doi.org/10.5380/rsa.v14i2.40891

GOLDEMBERG, J.; COELHO, S. T.; GUARDABASSI, P. The sustainability of ethanol production from sugarcane. Energy Policy, v.36, n.6, p.2086 - 2097, 2008. https://doi.org/10.1016/j.enpol.2008.02.028.

JIANG, J.; WANG, Y. P.; YU, M.; LI, K.; SHAO, Y.; YAN, J. Responses of soil buffering capacity to acid treatment in three typical subtropical forests. Science of The Total Environment, v.563, p.1068-1077, 2016. https://doi.org/10.1016/j.scitotenv.2016.04.198

KIRKELS, F. M. S. A.; CAMMERAAT, L. H.; KUHN, N. J. The fate of soil organic carbon upon erosion, transport and deposition in agricultural landscapes - A review of different concepts. Geomorphology, v.226, p. 94-105, 2014. https://doi.org/10.1016/j.geomorph.2014.07.023. 
KOMINKO, H.; GORAZDA, K.; WZOREK, Z. The Possibility of Organo-mineral fertilizer production from sewage sludge. Waste and Biomass Valorization. v.8, n.5, p.1781-1791, 2017.

https://doi.org/10.1007/s12649-016-9805-9

KOPRNA, R.; DIEGO, N. D.; DUNDÁLKOVÁ, L.; SPÍCHAL, L. Use of cytokinins as agrochemicals. Bioorganic \& Medicinal Chemistry. v.24, n.3, p.484-492, 2016.

https://doi.org/10.1016/j.wasman.2014.12.019

KULIKOWSKA, D.; GUSIATIN, Z. M. Sewage sludge composting in a two-stage system: Carbon and nitrogen transformations and potential ecological risk assessment. Waste Management.v.38, p.312-320, 2015. DOI 10.1016/j.wasman.2014.12.019

LIANG, Q.; CHEN, H.; GONG, Y.; YANG, H.; FAN, M.; KUZYAKOV, Y. Effects of 15 years of manure and mineral fertilizers on enzyme activities in particle-size fractions in a North China Plain Soil. European Journal of Soil Biology. v.60, p.112-119, 2014. http://dx.doi.org/10.1016/j.ejsobi.2013.11.009

OLIVEIRA, A. R. P.; ALVES, B. J. R.; ANJOS, L. H. C. dos.; LIMA, E.; ZONTA, E.; PEREIRA, W.; SOARES, P. F. C. Agronomic performance of green cane fertilized with ammonium sulfate in a coastal tableland soil. Bragantia, v.76, n.2, p. 246-256, 2017. http://dx.doi.org/10.1590/1678-4499.186

PIRES, A. M. M.; MATTIAZZO, M. E. Avaliação da viabilidade do uso de resíduos na agricultura Circular Técnica 19. Jaguariúna: EMBRAPA, 2008, 9p.

RADY, M. M. A novel organo-mineral fertilizer can mitigate salinity stress effects for tomato production on reclaimed saline soil. South African Journal of Botany,v.81, p.8-14, 2012.

https://doi.org/10.1016/j.sajb.2012.03.013

RAMOS, L. A.; LANA, R. M. Q.; KORNDÖRFER, G. H.; SILVA, A. de A. Effect of organo-mineral fertilizer and poultry litter waste on sugarcane yield and some plant and soil chemical properties. African Journal of Agricultural Research, v.12, n.1, p.20-27, 2017. https://doi.org/10.5897/AJAR2016.11024

RESENDE JÚNIOR, J. C.de.; CAMARGO, de R.; LANA, R. M. Q.; ALVES FILHO, A.; MATOS, A. L. A. The effects of sewage sludge, mineral and organic fertilizers on initial growth of Urochloa brizantha cv Marandu (Hochst. ex A. Rich.) R. D Webster. African Journal of Agricultural Research, v.11, n.36, p.34603470, 2016. https://doi.org/10.5897/AJAR2016.11477

SAVVAS, D.; NTATSI, G. Biostimulant activity of silicon in horticulture. Scientia Horticulturae, v.196, p.66-81, 2015. http://doi.org/10.1016/j.scienta.2015.09.010

SATTOLO, T. M. S.; MARIANO, E.; BOSCHIERO, B. N.; OTTO, R. Soil carbon and nitrogen dynamics as affected by land use change and successive nitrogen fertilization of sugarcane. Agriculture, Ecosystems \& Environment, v.247, p.63-74, 2017. http://doi.org/10.1016/j.agee.2017.06.005

SHARMA, H. S. S.; SELBY, C.; CARMICHAEL, E.; Mc ROBERTS, E.; RAO, J. R.; AMBROSINO, P.; CHIURAZZI, M.; PUCCI, M.; MARTIN, T. Physicochemical analyses of plant biostimulant formulations and characterisation of commercial products by instrumental techniques. Chemical and Biological Technologies in Agriculture. v.3, n.13, 2016. http://doi.org/10.1186/s40538-016-0064-6

SILVA, F. de A. S.; AZEVEDO, C. A. V. de. Principal components analysis in the software Assistat-Statistical Attendance. In: WORLD CONGRESS ON COMPUTERS IN AGRICULTURE, 7., 2009, Orlando. Anais... Reno, NV: American Society of Agricultural and Biological Engineers, 2009. 1CD-ROM.

SILVA, M. de. A.; CATO, S. C.; COSTA, A. G. F. Productivity and technological quality of sugarcane ratoon subject to the application of plant growth regulator and liquid fertilizers. Ciencia Rural, v.40, n.4, p.774-780, 2010. http://dx.doi.org/10.1590/S0103-84782010005000057 
TEIXEIRA, W. G.; SOUZA, R. T. X. de.; KORNDÖRFER, G. H. Response of sugarcane to doses of phosphorus provided by organomineral fertilizer. Bioscience Journal, v.30, n.6, p.1729-1736, 2014.

TOMEI, J. The sustainability of sugarcane-ethanol systems in Guatemala: Land, labour and law. Biomass and Bioenergy,v.82, p.94-100, 2015. https://doi.org/10.1016/j.biombioe.2015.05.018

USDA. United States Department of Agriculture. Sugar World markets and trade. Foreign Agricultural Service. Disponível em: https://www.fas.usda.gov/data/sugar-world-markets-and-trade. Acesso em: 13 set 2017.

YAN, W.; ZHONG, Y.; ZHENG, S.; SHANGGUAN, Z. Linking plant leaf nutrients/stoichiometry to water use efficiency on the Loess Plateau in China. Ecological Engineering, v.87, p.124-131, 2016.

https://doi.org/10.1016/j.ecoleng.2015.11.034

YILMAZ, E.; WZOREK, M.; AKÇAY, E. Co-pelletization of sewage sludge and agricultural wastes. Journal of Environmental Management, v. 216, p. 169-175, 2018. https://doi.org/10.1016/j.jenvman.2017.09.012 